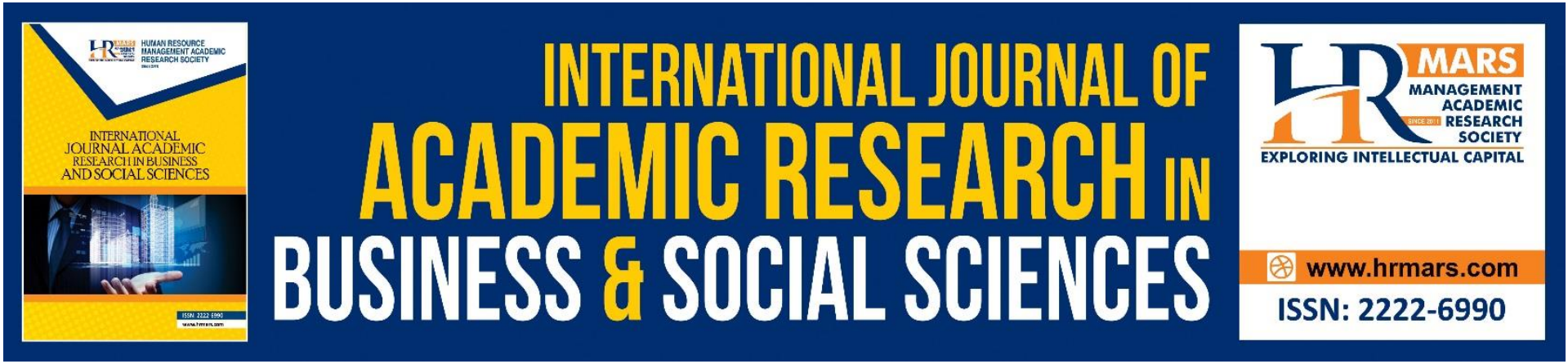

\title{
Issues and Trends of Teacher Professionalism for Malaysian Education
}

Salmi Abdul Patah, Yusof Boon

To Link this Article: http://dx.doi.org/10.6007/IJARBSS/v11-i4/9666

DOI:10.6007/IJARBSS/v11-i4/9666

Received: 05 February 2021, Revised: 07 March 2021, Accepted: 27 March 2021

Published Online: 14 April 2021

In-Text Citation: (Patah \& Boon, 2021)

To Cite this Article: Patah, S. A., \& Boon, Y. (2021). Issues and Trends of Teacher Professionalism for Malaysian Education. International Journal of Academic Research in Business and Social Science, 11(4), 248-254.

Copyright: (c) 2021 The Author(s)

Published by Human Resource Management Academic Research Society (www.hrmars.com)

This article is published under the Creative Commons Attribution (CC BY 4.0) license. Anyone may reproduce, distribute, translate and create derivative works of this article (for both commercial and non-commercial purposes), subject to full attribution to the original publication and authors. The full terms of this license may be seen at: http://creativecommons.org/licences/by/4.0/legalcode

Vol. 11, No. 4, 2021, Pg. 248 - 254

Full Terms \& Conditions of access and use can be found at http://hrmars.com/index.php/pages/detail/publication-ethics 


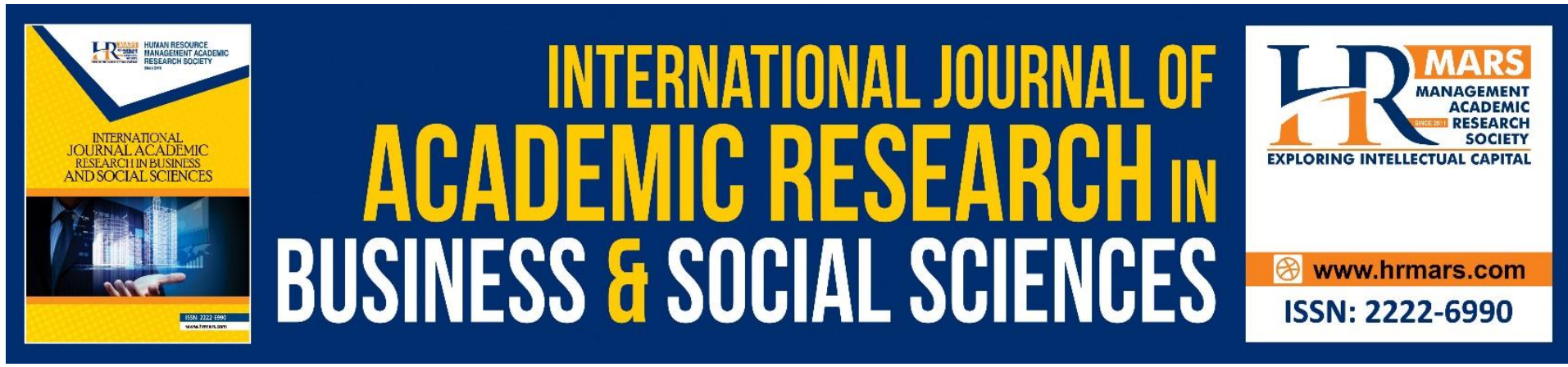

\title{
Issues and Trends of Teacher Professionalism for Malaysian Education
}

\author{
Salmi Abdul Patah, Yusof Boon \\ Universiti Teknologi Malaysia, Johor Bahru, Malaysia, Faculty of Social Sciences and \\ Humanities. \\ Email: salmeefattah@yahoo.com
}

\begin{abstract}
Every profession has a set of professional standards that must be met to ensure its quality and effectiveness, and teachers are no exception. As a result, in the Master Plan for the Growth of Teacher Professionalism and the Malaysian Teacher Standards, the Ministry of Education Malaysia has planned a professional development programme. However, teacher integrity problems and issues must be discussed and eliminated for the teaching profession to remain professional.
\end{abstract}

Keyword: Teacher Professionalism, Malaysia Education, Malaysian Teacher Standards

\section{Introduction}

The Malaysian Ministry of Education (MOE) is dedicated to training quality teachers, ensuring that quality individuals remain in the education sector, and ensuring that quality is maintained throughout the service. The Malaysian Teacher Standards (MTS) and the Integrated Assessment of Education Service Officers (IAESO) define the professional work competencies that teachers should possess, as well as the criteria that teacher training institutions should meet to assist teachers in achieving the required level of competency (Ministry of Education, 2013)

Meeting the MOE's expectations requires a collaborative effort that must be made and felt as a whole. The realisation of the MOE's hopes and ambitions involves participation at all levels, from the grassroots to the highest levels. Each educational group is involved in the implementation of the planned programme, either directly or indirectly. As a result, teachers have become the foundation of public education in the Malaysia. This is because the quality of teachers impacts educational quality (Ministry of Education, 2013).

Teachers' roles and responsibilities are growing, and the Malaysian Teacher Standards have established specific job efficiency standards that all Malaysian teachers must adhere to. Teachers must adhere to three criteria: professional values, knowledge and understanding, and teaching and learning abilities. As a result, the national education system will provide high-quality education that meets international standards (Ministry of Education, 2009). 


\section{Issues of Teacher Professionalism in Malaysia}

Since teachers do not understand the concept of teacher professionalism, MOE's National Education Philosophy, Vision, and Mission are less effective, resulting in a lower level of selfawareness of roles, duties, and key responsibilities as educators become less quality (Suhaimi, Hamzah \& Udin, 2011). The government's aim of becoming a developed country by 2020 is supported by the Ministry of Education's national empowerment of education initiative. Teachers are the cornerstone of a good curriculum and co-curriculum implementation, so all teachers at all levels must be mobilised and directed at the same time. It must be consistent with the MOE's objectives of producing qualified and knowledgeable teachers who are responsive to the country's needs.

Teachers' attitude toward change is one of the problems that contribute to a lack of teacher professionalism. Abu Hassan et al. (2018) found that teachers 'attitudes toward change were moderately resistant in general, and this is in line with Tai's study in 2017 that many teachers do not have teachers' attitudes toward change. Teachers' attitudes toward change can be improved through instruction, awareness, and understanding the lure of change among school teachers. As a result, school leaders must constantly express the importance of change in teachers' attitudes toward change.

Eroğlu \& Bektaş (2016) discovered that there are still some teachers who struggle to integrate subjects due to time and teaching materials. This aspect has a direct effect on the standard of instruction delivered by teachers in the classroom. When topics are introduced separately without incorporating the concept of learning and the real world, students' interest in learning is diminished, according to Radloff (2015). Different learning events must be introduced to strengthen teaching and learning in classrooms (Eroğlu \& Bektaş, 2016). Teachers' readiness in the aspect of insufficient knowledge and implementation should be given attention for further action by the relevant and responsible parties (Kassim \& Zakaria, 2015).

Several teachers fail to develop their skills, resulting in a loss of knowledge and a loss of professionalism. As a consequence, learning should not be limited to the university. Teachers' learning should not stop once they have completed their education at university but should continue until they have completed programmes to improve their selfprofessionalism after they have worked in the classroom. Continuous learning while on the job seeks to develop and empower teachers with the requisite knowledge and skills to keep up with changes in existing education policies and frameworks that strive to transform education to be better and more quality in line with global requirements (Ministry of Education, 2013; Mansor, Norwani \& Yunus, 2014).

Che Hassan and Abd Rahman (2011) explained that there are problems in teaching and learning, namely teachers' knowledge and skills. Weaknesses in mastering the subjects are common among teachers during the teaching and learning process. This will cause a feeling of disinterest and lazy to meet the aspects related to the subject. As well as possible, to embrace change in education, teachers must be prepared, constructive, qualified, and competent. The amount of knowledge gained is highly dependent on the teacher's ability, expertise, pedagogy, knowledge, and attitude. The success of learning in the classroom is measured by the awareness and attitudes of the teachers (Pau \& Yasin, 2021).

\section{Trend of Teacher Professionalism Development in Malaysia}

Research found that national school teachers in Peninsular Malaysia have a high degree of professionalism (Abu Hassan \& Musa, 2020), which is consistent with Yusof et al. (2018) but 
varies from the results of studies by Zabidi (2008), Syed Hassan et al. (2009), Idris et al. (2012), which found low and medium levels of teacher professionalism. This means that several variables cause this imbalance. Malaysia has adopted the Malaysian Education Development Plan (MEDP) 2013-2025, which states that all schools must achieve a culture of excellence. As a result, in 2014, the Teacher Education Division (TED) published the Continuing Professional Development Plan (CPDP), which states that Professional Learning Community (PLC) activities should be included as activities to increase teacher and school performance (Ministry of Education, 2014).

The focus on the growth of teacher professionalism (MOE Policy Planning \& Research Division, 2016) is one of the six initiatives taken by the MOE in the Trends in International Mathematics and Science Study (TIMSS) 2019 action plan to place Malaysia in the top onethird of international assessments to achieve the standard of system aspirations outlined in the Development Plan Malaysian Education 2013-2025. (DPME). This aligns with DPME 's fourth transition, which is to turn teaching into a career of choice. One of the transformations is to increase the standard of continuous professional development (CPD) programmes that lead to teacher readiness. CPD allows teachers to deepen and improve their professionalism while also improving the quality of student learning, according to Durksenet al. (2017). CPD in Malaysia's education system focuses on teachers' individual instructional needs and schoolbased preparation (Ministry of Education, 2013). As outlined in the Master Plan for the DPME launched in 2014, CPD activities or services include instruction, self-learning sessions, and Professional Learning Community (PLC).

PLC can be used to affect education improvement because of its effects on teacher pedagogical competence, which should be in line with current educational needs, where teachers must be diligent in developing their knowledge and skills during their careers (Darling-Hammond et al., 2009). According to Carol Jeanette Turner (2015), PLC is a method, technique, or culture type. The actions of educators who are committed to working collaboratively to conduct action research to improve student achievement are referred to as PLC (Eaker \& Many, 2006). Through collaboration to learn, develop, and enhance their professional practice, this PLC helps a community of educators to continuously strive to achieve their full potential and optimise student learning (Kristy Ann East, 2015).

In addition to PLC, other methods such as Teacher Coaching are used for teacher professional development. In the classroom, teaching coaching is where teachers can openly share their teaching experiences and pedagogical skills (Shulman, 1991). This collaboration will result in agreement among teachers who place a higher value on each other's confidence than their performance. Teaching Coaching is a means of assisting teachers in developing their classroom teaching by cultivating a supportive environment and facilitating reflective dialogue. It's a quick process in which teachers share their knowledge, give suggestions, motivate, and enhance learning by honing existing skills, learning new ones, and solving problems in the classroom (Mohd, 2006).

Teachers are encouraged to share best practices in teaching and learning in the classroom, according to the Ministry of Education (2013), and to use teaching coaching as a means of lifelong learning. This learning process depicts the evolution of teachers from phase to phase before they change their professional practice. Successful teaching guidance is based not just on the teacher's personal attributes but also on the role played by the educator, which includes leadership style, its contribution to the school's mission, principles, and priorities, and the approach used in the change process (Nordin, 2000; Cooper, 2003; Mahmood, 2008) 


\section{Conclusion and Future Agenda}

Teacher's professionalism and teacher's professionalism development are two separate issues that must be addressed together. Since a successful teacher professional development programme guarantees that teacher professionalism evolves perfectly and effectively, this is the case. The MOE's preparation is in line with the present educational situation and developments. Since several developed countries have proven this, the Professional Learning Community's adaptation (Ministry of Education, 2013) and teaching coaching as a system or tool in the growth of teacher professionalism is necessary and successful if the processes and procedures are carried out according to the correct mould. It is now the duty and obligation of teachers to develop their professionalism so that the MOE's targets for teacher quality and effectiveness can be met in the future. This is since teachers are the backbone of the country's growth and advancement. To ensure that teacher professionalism remains strong and high quality, all parties involved must collaborate from the top down to the bottom up. Since the strategies, equipment, and services have been given, the only people who need to move are the teachers and school leaders, as they are the foundation of Malaysia's educational system. Teachers should develop so that their primary duty is to ensure that students receive the best possible education.

Various theories of professionalism have proposed by international educational scholars such as Freidson, Evans and Sockett. The MOE has built a framework or model of teacher professionalism for Malaysian teachers, the Malaysian Teacher Standards (MTS). Malaysian Teacher Standards (MTS) is a standard that can be a benchmark for teachers and prospective teachers in Malaysia in producing quality teachers. In the Education Development Master Plan (EDMP), the teaching profession's direction and standards have clearly stated. MTS is a new guideline that has formed not only involving teachers but all parties involved in the education division. This MTS formulated to increase the level of teacher competence in the teaching and learning process and further increase the level of teacher professionalism in Malaysia. The practice of the values of teacher professionalism is formulated based on the culture of the Institute of Teacher Education, the Code of Ethics for the Teaching Profession, the noble values in the school curriculum, the core values in the Public Service, the main principles of MOE's Work Ethics, and the Twelve Pillars. This standard has three main domains, namely self, profession and society.

\section{References}

Abu Hassan, M. A., \& Musa, K. (2020). Tahap profesionalisme guru sekolah kebangsaan di Semenanjung Malaysia. Management Research Journal, 9(2), 37-45.

Abu Hassan, M. A., Rabbani, M. F., Shukor, M. E., \& Abdul Majid, M. M. (2018). Sikap Guru Terhadap Perubahan dalam Sekolah di Malaysia. Management Research Journal, 7, 188 - 196.

Mohd, A. H. (2006). Guru sebagai pendorong dalam darjah. Selangor: PTS Professional. Carol Jeanette Turner. (2015). Impact of Professional Learning Community Design on Teacher Instruction. Doctoral, University of Arkansas.

Che Hassan, C., \& Abd Rahman, F. (2011). Pelaksanaan Pengajaran Dan Pembelajaran Kemahiran Menulis di Sekolah Rendah. Jurnal Pendidikan Bahasa Melayu, 1(1), 67-87.

Cooper, J. (2003). Leadership for follower commitment. Burlington: Butterworth Heinemann. 
Darling-Hammond, L., Wei, R., Andree, A., Richardson, N. \& Orphanos, S. (2009). Professional learning in the learning profession: A status report on teacher development in the United States and abroad.

DuFour, Eaker \& Many. (2006). Learning by doing: A handbook for professional learning communities at work. Solution Tree, Bloomington, IN.

Durksen, T.L., Klassen, R.M. \& Daniels, L.M. (2017). Motivation and collaboration: The keys to a developmental framework for teachers' professional learning. Teaching and Teacher Education,7, 53-66.

Eroğlu, S., \& Bektaş, O. (2016). STEM eğitimi almış fen bilimleri öğretmenlerinin stem temelli ders etkinlikleri hakkındaki görüşleri. Eğitimde Nitel Araştırmalar Dergisi - Journal of Qualitative Research in Education, 4(3), 43-67.

Idris, N., \& Hamzah, R. (2012). Nilai profesionalisme bakal guru berteraskan indikator standard guru Malaysia (SGM). Jurnal Teknologi, 31-37.

Kassim, N., \& Zakaria, E. (2015). Integrasi kemahiran berfikir aras tinggi dalam pengajaran dan pembelajaran matematik: Analisis keperluan guru. In Prosiding Seminar Education Graduate Regional Conference (EGRC 2015).

Kristy Ann East. (2015). A Study of Professional Learning Communities: Characteristics of Implementation and Perceived Effectiveness in Improvement Schools in West Virginia. Doctoral Thesis, Marshall University.

Pau, S., \& Yasin, M. (2021). Pengetahuan dan sikap guru aliran perdana terhadap program pendidikan inklusif di daerah Sibu. Jurnal Dunia Pendidikan, 3(1), 515-529.

Mahmood, H. (2008). Kepemimpinan dan keberkesanan sekolah (2nd ed.). Kuala Lumpur: Dewan Bahasa dan Pustaka.

Mansor, M., Norwani, M. N., \& Yunus, J. (2014). Hubungan antara model-model pembelajaran profesional terhadap amalan guru sekolah menengah harian di Malaysia. Jurnal Pendidikan Bitara UPSI, 6(5).

Ministry of Education. (2013). Pelan Pembangunan Pendidikan Malaysia 2013-2025. Putrajaya: Kementerian Pendidikan Malaysia.

Ministry of Education. (2014). Buku Pelan Pembangunan Profesionalisme Berterusan. Putrajaya: Kementerian Pendidikan Malaysia.

MOE Policy Planning \& Research Division. (2016). Laporan TIMSS 2015. Putrajaya: Kementerian Pendidikan Malaysia.

Zabidi, M. N. (2008). Persepsi pentadbir sekolah terhadap kualiti guru pelatih UTM di sekolah sekitar Johor Bahru (Unpublished bachelor dissertation). Universiti Teknologi Malaysia.

Nordin, A. (2000). Gaya kepemimpin pengetua cemerlang di dua buah sekolah menengah kebangsaan di Negeri Sembilan (Unpublished doctoral dissertation). Universiti Kebangsaan Malaysia.

Radloff, J. (2017). Investigating changes in preservice teachers' conceptions of stem education following video analysis and reflection. School Science and Mathematics, 117(3-4), 158-167

Suhaimi, N., Hamzah, R., \& Udin, A. (2011). Profesionalisme guru PTV dalam membentuk insan sedar kendiri (self-actualization). Journal of Edupress, 1, 230-237.

Hassan, S., Tamuri, A., Othaman, I., \& Mamat, M. (2009). Kajian persepsi pelajar terhadap tahap profesionalisme guru Pendidikan Islam MRSM. JIAE: Journal of Islamic and Arabic Education, 1(2), 31-50. 
INTERNATIONAL JOURNAL OF ACADEMIC RESEARCH IN BUSINESS AND SOCIAL SCIENCES Vol. 11, No. 4, 2021, E-ISSN: 2222-6990 @ 2021 HRMARS

Yusof, H., \& Chan, M. (2018). Hubungan profesionalisme guru dengan kepimpinan guru di sekolah jenis kebangsaan cina, Sarawak. Management Research Journal, 7, 1-12. 